\title{
Pengaruh Intervensi Gizi Olah Raga Terhadap Kadar Kholesterol, Asupan Karbohidrat, Protein, Lemak Dan Volume Oksigen $\left(\mathrm{VO}_{2}\right)$ Maksimum Usia Dewasa
}

\author{
Sirajuddin \\ Jurusan Gizi, Poltekkes Kemenkes Makassar
}

\begin{abstract}
ABSTRAK
Gizi olah raga adalah sebuah intervensi gizi kepada subjek yang diteliti selama 2 bulan intervensi berupa pendidikan gizi yang terintegrasi dengan materi kebugaran, aktivitas fisik. Tujuan penelitian ini adalah untuk mengetahui efek intervensi gizi olah raga terhadap pengetahuan gizi, kadar kolesterol, VO2 max, Asupan Karbohidrat, Protein dan Lemak. Metode penelitian ini adalah experiment semu dengan kelompok control. Besar sampel adalah 7 orang kelompok intervensi dan 13 kelompok control. Data kolesterol diambil dari darah kapiler menggunakan Human KIT, Data VO2 max diambil dengan test cooper, data antropometri dengan timbangan seca dan stadiometer ketelitian masing masing $(0,1 \mathrm{~kg})$ dan $(0,1 \mathrm{~cm})$. pendidikan ayah adalah umumnya tamat SMA pada kelompok intervensi $(57,1 \%)$ dan Perguruan Tinggi $(92,3 \%)$ pada kelompok kontrol. Pendidikan ibu juga $57,1 \%$ tamat SMA pada kelompok intervensi dan $84 \%$ tamat perguruan tinggi pada kelompok kontrol. Status gizi obesitas $85 \%$ pada kelompok intervensi dan $69 \%$ kurus pada kelompok kontrol. Intervensi gizi olah raga berpengaruh pada perubahan skor pengetahun gizi pada kelompok intervensi dan kontrol masing masing $p=0,000$ dan $p=0,000$. Tetapi tidak berbeda pada kedua kelompok diawal maupu diakhir intervensi $(p>0,050)$. Asupan gizi makro tidak berubah pada kedua kelompok $(p>0,050)$. Kadar Kholesterol Total juga tidak berubah $(p>0,050)$ dengan intervensi gizi olahraga 8 minggu intensitas 3 hari seminggu durasi 1 jam. Volume Oksigen Maksimum $\left(\mathrm{VO}_{2}\right.$ Maks) berubah secara signifikan pada kelompok intervensi $(\mathrm{p}=0,002)$. Kesimpulan intervensi gizi olahraga 8 minggu, intensitas minimal 3 kali dengan durasi minimal 60 menit mampu meningkatkan volume oksigen maksimun.
\end{abstract}

Kata Kunci : Gizi Olah Raga, VO2 Maksimum dan Kholesterol

PENDAHULUAN

Tujuan utama pembangunan kesehatan global 2020 adalah pengembangan promosi hidup sehat dan perilaku sehat pada semua siklus kehidupan. Pendidikan gizi tidak hanya masalah makanan tetapi juga pengaturan aktifitas fisik (Lyons 2014) Data Aktifitas fisik penduduk Indonesia masih kurang yaitu $48,2 \%$ pada usia $>10$ tahun dan Sulawesi Selatan termasuk salah satu propinsi dengan persentase aktifitas fisik kurang. Secara nasional aktifitas fisik terendah adalah penduduk Kota Padang 11,9\% dan kota dengan penduduk aktifitas fisik tertinggi adalah Pacitan 68,3\%. (Balitbangkes 2013)

Data aktifitas fisik penduduk Sulawesi Selatan tahun 2013, pada kelompok usia dewasa 20-24 tahun masing masing untuk aktivitas $<3$ jam, 3-5 jam dan $>6$ jam berturut turut adalah $46,3 \%, 38,0 \%$ dan $15,7 \%$. Data ini membuktikan bahwa gaya hidup sedentary cenderung meningkat dengan bertambahnya usia, pada saat yang sama kebugaran semakin dibutuhkan untuk peningkatan kinerja. Perbaikan aktifitas fisik melalui pekerjaan harian ataupun kegiatan olah raga adalah penting untuk melawan dan mencegah efek negatif gaya hidup sendentary (Balitbangkes 2013)

Intervensi gizi olahraga dalam bentuk edukasi gizi olahraga dan latihan fisik secara teratur diyakini memberi efek positif pada peningkatan pengetahuan, perbaikan kadar kolesterol, keseimbangan asupan karbohidrat, protein, lemak, $\mathrm{VO}_{2}$ max. Hal ini didasarkan pada berbagai riset terdahulu (Abeysekara et al. 2012), (Annesi 2013), (Barreira et al. 2014), (Bird 2010) Pengetahuan gizi olah raga memberikan efek positif pada penataan berat badan dan aktifitas fisik sehingga meningkatkan kebugaran. Implementasi pengetahuan gizi pelatih bahkan sudah diterapkan pada pusat latihan atlet di Kanada dan hasilnya adalah performa atlet menjadi lebih baik.(Gibson et al. 2011), (Ahuja \& Bharti 2014), (Royall 2015). VO2 max adalah volume maksimal oksigen yang diproses oleh tubuh manusia pada saat melakukan kegiatan intensif. Volume oksigen ini adalah merujuk pada kemampuan tubuh yang dinyatakan dalam liter per menit atau mili liter per menit per $\mathrm{kg}$ berat badan.Semakin baik nilainya maka semakin baik daya tahan atlet.(Nursing \& Source 2009), (Mann et al. 2014), (Habibi et al. 2014) 
Asupan gizi makro dan gizi mikro adalah penting untuk meningkatkan daya tahan tubuh. Gizi seimbang dapat memberikan kontribusi yang cukup signifikan pada pencapaian status kesehatan dan kebugaran setiap orang.(Torres-mcgehee et al. 2012), (Mujika \& Burke 2011), (Maughan \& Shirreffs 2012), (Papadopoulou \& Papadopoulou 2010)
Tujuan Penelitian adalah mengetahui tingkat pengetahuan gizi , level $\mathrm{VO}_{2}$ max, kadar kolesterol, asupan karbohidrat, protein, lemak sebelum dan setelah intervensi

\section{METODE PENELITIAN}

Disain penelitian adalah experiment semu, dengan disain pre postest control disain.

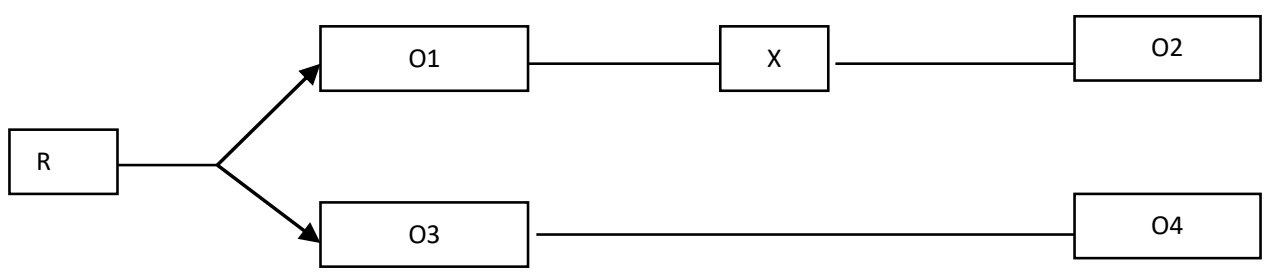

Bagan 1. Randomized Pretest Posttes Control Group Design

Keterangan

$\mathrm{R}=$ Randomisasi

X1=Intervensi Gizi Olahraga (Edukasi Materi Gizi Olahraga, Latihan Fisik)

O1= Pengukuran Kholesterol, Asupan KH, Protein, Lemak, VO2 max sebelum intervensi pada kelompok Intervensi

$\mathrm{O} 2$ = Pengukuran Kholesterol, Asupan KH, Protein, Lemak, VO2 max setelah intervensi pada Kelompok Intervensi

O3= Pengukuran Kholesterol, Asupan KH, Protein, Lemak, VO2 max sebelum intervensi pada kelompok Kontrol

O4 = Pengukuran Kholesterol, Asupan KH, Protein, Lemak, VO2 max setelah intervensi pada Kelompok Kontrol

Skreening subjek dilakukan untuk melakukan menentukan kelompok intervensi dan kelompok control. Kelompok intervensi menerima edukasi gizi olah raga kelas kecil rada sedangkan kelompok control Tidak menerima intervensi gizi. Kriteria inklusi usia> 19 tahun, berbadan sehat, tidak sedang menjalankan diet khusus. Kriteia ekslusi (1) Drop out dalam penelitian (2) menderita sakit saat intervensi dan menolak setelah menunjukan persetujuan.

Populasi dan Sampel

Populasi adalah remaja usia produktif yang berdomisili di sekitar Kampus Jurusan Gizi Politeknik
Kesehatan Makassar. Jln Paccerakkang Km 14 Daya.

Besar sampel dihitung berdasarkan rumus pengambilan sampel berikut ini:

$$
\begin{array}{rlr} 
& \mathrm{n}=\frac{(Z 1-\alpha+Z 1-\beta) x^{2} \sigma^{2}}{} \\
\mathrm{n} \quad(U 1-U 2) & \\
Z 1-\alpha \quad & \text { besar sampel } \\
& =\text { nilai } Z \text { pada kurva } \\
& \text { normal untuk tingkat } \\
& \text { kemaknaan } 0,05 \\
& \text { adalah 1,64 satu } \\
& \text { arah } & \\
Z 1-\beta \quad & \text { nilai } \mathrm{Z} \text { kurva } \\
& \text { normal dengan } \\
& \text { kekuatan uji (power } \\
& \text { test) adalah } 0,2 \\
& \text { adalah 1,285 }
\end{array}
$$


U1

U2

$$
\begin{aligned}
& \text { adalah rata rata nilai } \\
& \text { VO2 maks } \\
& \text { latihan rebelum } \\
& \text { sebelumnya } \\
& \text { riset } \\
& 25,06 \\
& =\text { adalah } \\
& \text { nilai volah rata tara } \\
& \text { setelah latihan pada } \\
& \text { riset sebelumnya } \\
& \text { adaaj } 28,7
\end{aligned}
$$

Jadi sampel perlakuan adalah 14 orang yang dibagi menjadi 7 orang intervensi dan 7 orang kontrol.

\section{Teknik Penarikan Sampel}

Penarikan sampel dalam penelitian ini dilakukan secara acak sederhana dari kerangka sampel yang telah disusun. Langkah pertama dibuat kerangka sampel dan selanjutnya di kelompokkan menjadi dua bagian masing masing kelompok obesitas, overweight dan underweight sebagai kelompok intervensi dan kelompok berstatus gizi normal sebagai kelompok control.

\section{Lokasi Penelitian}

Lokasi penelitian adalah Kelurahan Paccerakkang RT 10 RW 01 Kecamatan Biringkanaya Kota Makassar.Pelaksanaan intervensi berpusat di Laboratorium PSG Jurusan Gizi Politeknik Kesehatan Makassar dan Lapangan Olah raga Jurusan Gizi Politeknik Kemenkes Makassar.

\section{Teknik Pengumpulan Data}

Teknik pengumpulan data dapat diuraikan sebagai berikut:

1. Data Status Gizi diketahui berdasarkan data antropometri BB, dan Tinggi Badan. Alat ukur adalah timbangan Seca Ketelitian 0,1 kg. Ukuran Tinggi Badan dengan Stadiometer Ketelitian 0,1 cm

2. Data Kadar Kholesterol dengan KIT Human, memakai darah kapiler. Pengambilan darah oleh laboran analisis kesehatan Jurusan Gizi Poltekkes Kemenkes Makassar

3. Data VO2 max dikumpulkan dengan metode Balke Test. Persiapan test Balke adalah Lintasan lari 400 meter dan Stopwacth, pencatat jarak tempuh. a. Subjek melakukan pemanasan (warm up) 10-15 menit,

b. Kemudian subjek berlari selama 15 menit dan dicatat jarak yang diempuhnya sampai dengan 100 $\mathrm{m}$ terdekat.

c. Setelah selesai berlari, subjek melakukan pendinginan (cooling down) kemudian hasil yang ditempuh subjek selama 12 menit dicocokkan dengan tabel klasifikasi Balke Test

4. Data Konsumsi dengan Recall Konsumsi $2 \times 24$ Jam. Di analisis dengan Nutrisurvey. Enumerator adalah Mahasiswa DIV Gizi yang telah lulus mata kuliah survey Konsumsi Makanan

5. Quality Control dengan supervise pelaksanaan pengumpulan data oleh peneliti

\section{HASIL DAN PEMBAHASAN}

\section{Karakteristik Responden}

Berdasarkan hasil penelitian ini (Tabel 1) diketahui bahwa pendidikan ayah pada kelomok intervensi dan kontrol adalah tamat SMA dan Perguruan Tinggi masing masing $57,1 \%$ dan $92,3 \%$. Pendidikan ibu adalah tamat SMA dan Perguruan tinggi masing masing $57,2 \%$ dan $84,6 \%$. Status gizi pada subjek pada penelitian ini untuk kelompok intervensi dan kontrol adalah obesitas 1 dan Kurus masing masing $85,7 \%$ dan $69,2 \%$

\section{Pengetahuan Gizi}

Berdasarkan hasil penelitian ini (Tabel 2) diketahui bahwa tida ada perbedaan pengetahuan gizi sebelum dan setelah intervensi baik pada kelompok intervensi maupun pada kelompok kontrol dengan signifikansi masing masing $\mathrm{p}=0,999$ dan $\mathrm{p}=0,456$. Berdasarkan hasil penelitian ini (Tabel 3) diketahui bahwa tidak ada perbedaan pengetahuan gizi sebelum dan setelah intervensi $(p=0,063)$ pada kelompok intervensi tetapi pada kelompok kontrol ditemukan perbedaan signifikansi $(p=0,016)$

\section{Asupan Gizi Makro}

Hasil uji normalitas data dengan test Kolomogorof Semirnof diketahui bahwa asupan Kabohidrat, Pemak dan 
Energi adalah berdistribusi normal $(p>0,05)$ sehingga dapat digunakan analisis $\mathrm{t}$ test. Akan tetapi khusus untuk asupan protein diketahui bahwa datanya tidak berdistribusi normal sehingga digunakan test U Man Withney dan Mc Nemar Test. Hasil penelitian diketahui bahwa tidak ada perbedaan asupan gizi sebelum dan setelah intervensi pada kedua kelompok $(p>0,05)$.

Hasil penelitian tentang asupan gizi makro (Tabel 4 dan Tabel 5) diketahui bahwa asupan gizi makro (Karbohidrat, Protein, Lemak dan Asupan Energi) adalah pada umumnya tidak berbeda $(p>0,05)$ kecuali asupan protein berbeda nyata baik sebelum maupun setelah intervensi antar kelompok masing masing $p=0,000$ dan $\mathrm{p}=0,011$. Asupan lemak setelah intervensi antar kelompok berbeda $(p=0,013)$. Asupan energi berbeda diawal dan diakhir intervensi masing masing $p=0,019$ dan $p=0,024$.

\section{Kholesterol Total}

Hasil penelitian ini (Tabel 6) diketahui bahwa tidak ada perbedaan kadar kholesterol sebelum dan setelah intervensi pada kedua kelompok masing masig $p=0,774$ untuk kelompok intervensi dan $p=0,252$ untuk kelompok kontrol.

Jika dibandingkan kadar kholesterol sebelum intervensi antar kedua kelompok ditemukan ada perbedaan $(p=0,015)$ demikian juga pada akhir intervensi dengan signifikansi $p=0,008$. (Tabel 7)

\section{$\mathrm{VO}_{2}$ Maksimum}

Volume oksigen maksimum pada kelompok intervensi meningkat signifikan $\mathrm{p}=0,001$ sedangkan pada kelompok kontrol tidak meningkat $p=0,054$. Hal ini membuktikan bahwa peningkatan VO2 maksimum dapat dilakukan dengan latihan teratur 3 kali seminggu masing masing 1 jam untuk setiap kali latihan jalan cepat dan lari ringan. (Tabel 8)

Volume oksigen maksimum
antara kelompok intervensi
dibandingkan dengan kontrol diawalnya
adalah berbeda $(p=0,022)$ dan
perbedaan semakin nyata setelah
intervensi dengan $p=0,002$ Perlu
diketahui bahwa pengelompokan

peserta dalam penelitian ini adalah berdasarkan status gizi bukan berdasarkan variasi VO2 maksimum, sehingga ditemukan kondisi awal sudah berbeda VO2 maksimumnya (Tabel 9)

\section{Pembahasan}

Pengetahuan Gizi subjek pada penelitian ini adalah tidak mengalami peningkatan secara signifikan $(p=)$ baik pada kelompok kontrol maupun pada kelompok intervensi. Pada kelompok intervensi peningkatan pengetahuan adalah akibat penyampaian pesan singkat melalui jejaring sosial (LINE) yang dipilih sebagai saluran komunikasi pada kelompok penelitian ini yang diberi nama sharing student yang beranggotakan semua peserta dalam penelitian ini. Peneliti tidak mengisolasi kelompok kontrol atas akses informasi pengetahuan gizi olah raga atas dasar etika penelitian dan seluruh subjek adalah dalam masa studi.

Hasil penelitian ini menemukan fakta bahwa pengetahuan gizi tidak meningkat secara signifikan pada kedua kelompok. Hal ini disebabkan karena beberapa faktor antara lain instrumen pengetahuan yang masih terlalu sukar untuk diinterpretasi oleh subjek. Meskipun instrumen ini sudah melalui tahap ujicoba sebelumnya. Pengetahuan gizi olah raga adalah pengetahuan yang memadukan komponen pengetahuan gizi secara umum dan pengetahuan tentang kesehatan olahraga dianggap masih awam pada subjek. Fokus kajian pada gizi olah raga sudah menyesuaikan pada materi tentang gizi seimbang pada kegiatan olahraga.

Penelitian yang lain membuktikan bahwa pengetahuan gizi olah ragawan adalah hal penting untuk penampilan atlet.Diteliti pada pemain sepak bola India, 200 orang pemain diteliti tentang pengetahuan gizinya dan asupan gizi.hasilnya diketahui bahwa asupann karbohidrat, dan protein, serta lemak omega 3 memberikan efek positif terhadap daya tahan tubuh pemain. Sehingga pemain bola perlu dilakukan konseling gizi seimbang dalam bentuk konseling kelompok sesuai dengan teamnya (Ahuja \& Bharti 2014)

$$
\text { Pengetahuan gizi bagi }
$$$$
\text { olahragawan adalah penting. Hal ini }
$$ 
didukung riset lain yang membuktikan bahwa persiapan atlet sebelum kompetisi bukan hanya persiapan teknis bertanding tapi perlu didampingi oleh konsultan dietesien. Atlet Kanada telah menerapkan hal ini dengan membentuk team dietesien untuk atlet. Hasilnya seluruh atlet memiliki performa yang terbaik saat kompetisi (Royall 2015) Implementasi gizi olah raga telah diteliti di Canada.Fokus risetnya adalah pada pengetahuan gizi pelatih dan kemampuan memberikan rekomendasi variasi pelatihan berdasarkan performa status gizi pemain. Hasilnya diketahui bahwa semakin bagus pengetahuan gizi pelatih maka ia akan mampu menyesuaikan beban atlet dengan beban latihan yang akhirnya berdampak pada pencapaian prestasi maksima (Danaher 2014)

Pengetahuan gizi olah raga tidak hanya penting bagi pelatih tetapi pada semua pihak yang menjadi pengelola sebuah team olahraga. Penelitian tentan pengetahuan dan implementasi gizi olah raga diteliti secara cross sectional study pada 579 atlet yang terdiri dar 186 pemain, 131 pelatih, dan asisten pelatih 192 orang dan manajemen 71 orang. Hasilnya diketahui bahwa pengetahuan gizi olahraga diperlukan untuk meningkatkan prestasi dan pengendalian berat badan.(Torresmcgehee et al. 2012), (Mujika \& Burke 2011)

Prestasi atlet dipengaruhi oleh banyak faktor, talenta, sistem pelatihan, motivasi, dan faktor gizi atlet.Membentuk otot, rendah karbohidrat, tinggi lemak, berat badan ideal, dietary suplement, asupan cairan dan nutrisi otak.(Maughan \& Shirreffs 2012)

Kapasitas konselor gizi olah raga dapat berasal dari pendidikan gizi yang liner ataupun yang tidak linier dari berbagai disiplin ilmu kesehatan masyarakat. Dietesien yang menangani kasus gizi olah raga di Kanada memiliki latar belakang pendidikan gizi yang berbeda beda. (Gibson et al. 2011)

Aktifitas Fisik memiliki korelasi positif dengan kinerja jantung, pernapasan, pencernaan dan jaringan otot.Penelitian di Yunani terhadap pemain bola, bola basket. Hasilnya diketahui bahwa olahragawan memiliki kinerja jantung, pernapasan, pencernaan dan jaringan otot dan berkorelasi dengan asupan protein, vitamin A, B1, B12, Asam Folat dan Phospor. (Papadopoulou \& Papadopoulou 2010) Berdasarkan riset diatas maka diketahui bahwa pada umumnya efek olahraga adalah menurunkan kolesterol.(Mann et al. 2014)

Asupan Gizi subjek pada penelitian ini adalah sama sebelum dan setelah intervensi pada kedua kelompok. Asupan gizi adalah variabel yang tidak mudah berubah karena berhubungan dengan kebiasaan makan. Kebiasaan makan adalah variabel psiko sosial yang sangat konsisten dipelihara oleh setiap subjek. Perubahan kebiasaan makan hanyalah dipicu oleh bukti empiris lahirnya cara baru yang diyakini memang dapat memberikan keuntungan bagi subjek.

Aspek lain yang menjelaskan mengapa konsumsi makanan sulit berubah adalah Kepuasan terhadap makanan adalah variabel penting untuk meningkatkan kecukupan konsumsi pada usia lanjut. Salah satu cara meningkatkan kepuasan terhadap makanan adalah dengan menguji berbagai makanan baru kepada kelompok usia lanjut. Metode yang digunakan adalah display makanan setiap bulan ditempat rekreasi atau ruang publik yang banyak dikunjungi oleh mereka. Riset ini memiliki 3 variabel yaitu 1.Buat Display makanan baru, 2.Buat Resep makanan yang didisplay dan 3.Angket terhadap kegiatan display.Settingnya adalah Setiap akhir pekan makanan baru di disuplai di tempat rekreasi diawai oleh ahli gizi sebagai edukator.Setiap yang berminat untuk mencicipi diberikan instruksi untuk mengambil resepnya dan mencoba melakukannya di rumah. Hasilnya akan mereka kirimkan kembali angketnya. Riset ini dilakukan selama 3 minggu. Temuan dalam riset ini adalah bahwa mereka yang menyukai makanan baru akan membuatnya sendiri di rumah dan meningkatkan asupan gizi. Terhadap resep yang meraka coba secara mandiri diberi kesempatan untuk merubah sesuai selera dan dapat berbagi dengan peneliti tentang itu.(Barbara Manilla, Heather H.Keller 
2010)(Barbara Manilla, Heather H.Keller 2010)

Asupan gizi yang diketahui berubah secara kuantitatif dapat saja disebabkan oleh metode pengukuran, namun dalam penelitian ini hal itu tidak ditemukan karena terbukti tidak ditemukan perbedaan asupan zat gizi makro pada kelompok intervensi maupun kelompok kontrol. Asupan gizi pada penelitian ini bukanlah variabel yang ditonjolkan dalam fokus gizi olah raga. Hal ini atas dasar pertimbangan bahwa masa dewasa awal > 19 tahun adalah masa yang masih labih dalam pemenuhan asupan gizi. Labil yang dimaksudkan adalah dapat berubah menjadi defisit atau kelebihan asupan. Menghindari risiko kekurangan lebih penting daripada berhadapan dengan kelebihan asupan. Kelebihan asupan dapat diimbangi dengan aktifitas fisik yang teratur. Penelitian ini memberikan perlakuan pokok berupa aktifitas fisik untuk kelompok intervensi. Kelompok intervensi adalah subjek yang sudah obesitas, sehingga pengurangan asupan secara drastis dipandang mempersulit keberlanjutan riset. Asupan gizi makro dan gizi mikro adalah penting untuk meningkatkan daya tahan tubuh. Gizi seimbang dapat memberikan kontribusi yang cukup signifikan pada pencapaian status kesehatan dan kebugaran setiap orang.(Torresmcgehee et al. 2012), (Mujika \& Burke 2011), (Maughan \& Shirreffs 2012), (Papadopoulou \& Papadopoulou 2010) Kholesterol adalah cadangan energi dalam tubuh disamping fungsi fisiologis yang lain seperti pelarut vitamin. Kholesterol total dalam penelitian ini adalah tidak berubah selama 8 minggu intervensi $(p>0,05)$. Hal ini memberikan bukti bahwa perubahan kadar kholesterol dengan intervensi gizi olahraga fokus pada aktivitas fisik adalah memerlukan waktu lama untuk mengalami penurunan. Fakta ini menguatkan konsep bahwa intervensi penurunan kadar kholesterol adalah intervensi gaya hidup yang lama dan konstan. Waktu paruh kolesterol dalam darah adalah juga penting diperhatikan sehingga lama intervensi dapat diketahui dengan pasti. Hasil penelitian ini sejalan dengan penelitian lain yang membuktikan bahwa perubahan kadar kholesterol akibat latihan adalah sangat lama untuk dicapai dengan keteraturan dan ketekunan. (Abeysekara et al. 2012), (Annesi 2013), (Barreira et al. 2014), (Bird 2010)

Volume Oksigen Maksimun pada penelitian ini adalah berbeda nyata pada kelompok intervensi dan tidak pada kelompok kontrol. Intervensi gizi olah raga dapat menjadi alternatif untuk meningkatkan kinerja subjek penelitian. Secara teori VO2 max adalah volume maksimal oksigen yang diproses oleh tubuh manusia pada saat melakukan kegiatan intensif. Volume oksigen ini adalah merujuk pada kemampuan tubuh yang dinyatakan dalam liter per menit atau mili liter per menit per $\mathrm{kg}$ berat badan.Semakin baik nilainya maka semakin baik daya tahan atlet.(Nursing \& Source 2009), (Mann et al. 2014), (Habibi et al. 2014)

\section{KESIMPULAN}

Pengetahuan Gizi tidak meningkat dengan intervensi gizi olah raga. Asupan Gizi Makro tidak dapat berubah secara signifikan pada intervensi gizi olah raga selama 8 minggu.Kholesterol Total, tidak dapat berubah secara signifikan dengan intervensi gizi olah raga 8 minggu. Volume Oksigen Maksimum (VO2 Maks) dapat meningkat dengan intervensi 8 minggu dengan intensitas 3 hari dalam seminggu durasi 60 menit setiap aktifitas fisik berubah jalan cepat dan lari ringan.

Intervensi gizi olahraga dapat dijadikan database penelitian lanjutan untuk mengetahui efeknya dalam jangka panjang terhadap profile lipid. Penelitian lanjutan untuk mengetahui efek intervensi gizi olahraga terhadap kholesterol subjek, dengan alasan penelitian 8 minggu diyakini belum mampu memberikan efek yang nyata atau berpotensi untuk menghasilkan negatif palsu.

\section{DAFTAR PUSTAKA}

Abeysekara, S. et al., 2012. A pulsebased diet is effective for reducing total and LDL-cholesterol in older adults.

Ahuja, P. \& Bharti, V., 2014. Nutrition 
Knowledge of Football Players and Formulation of an Effective Nutrition Communication Package. International Journal of Food $N$, 2(2), pp.63-67.

Annesi, J.J., 2013. Association of multimodal treatment-induced improvements in stress, exercise volume, nutrition, and weight with improved blood pressure in severely obese women. International Journal of Behavioral Medicine, 20(3), pp.397-402.

Balitbangkes, 2013. Riset Kesehatan Dasar Propinsi Sulawesi Selatan 2013 Pertama., Jakarta: Balitbangkes.

Banna, J.C. \& Townsend, M.S., 2011. Assessing factorial and convergent validity and reliability of a food behaviour checklist for Spanishspeaking participants in US Department of Agriculture nutrition education programmes. Public health nutrition, 14(7), pp.11651176.

Barbara Manilla, Heather H.Keller, M.R.H., 2010. Food Tasting as Nutrition Education. Canadian Journal of Dietetic Practioce and Research, 72(2), pp.99-102.

Barreira, T., Harrington, D. \& Katzmarzyk, $\quad$ P., 2014. Cardiovascular health metrics and accelerometer-measured physical activity levels: National Health and Nutrition Examination Survey, 2003-2006. Mayo Clinic proceedings, 89(1), pp.81-6. Available at: http://www.ncbi.nlm.nih.gov/pubme $\mathrm{d} / 24388025$.

Bird, S., 2010. Strength Nutrition: Maximizing Your Anabolic Potential. Strength and Conditioning Journal, 32(4), pp.8086.

Brug, J. et al., 2005. The internet and nutrition education: challenges and opportunities. European Journal of Clinical Nutrition, 59(Supp 1), pp.130-140.

Cavanna, L. \& Roth, M., 2010. Eat Well, $\mathrm{Be}$ Well Nutrition Education Program: Westchester and Lower Putnam County, New York. Childhood obesity (Print), 6(6), pp.350-353.
Cynthia Strawson, Rhonda Bell, Shaunda Downs, Anna Farmer, Dana Olstad, noreen willows, 2013. Dietary Patterns of Female University Students. Canadian Journal of Dietetic Practice \& Research, 74(3), pp.138-142.

Danaher, K., 2014. Nutrition Knowledge and Practices of Varsity Coaches at a Canadian University. Canadian Journal Diet Research, 75, pp.210-213.

Dunneram, Y. \& Jeewon, R., 2015. Healthy Diet and Nutrition Education Program among Women of Reproductive Age: A Necessity of Multilevel Strategies or Community Responsibility. Health Promotion Prospectives, 5(2), pp.116-127. Available at: http://dx.doi.org/10.15171/hpp.201 5.014 .

Falter, R.A. et al., 2011. INSTRUCTIONAL DESIGN AND ASSESSMENT A Service Learning Program in Providing Nutrition Education to Children. American Journal of Pharmaceutical Education, 75(5), pp.1-8.

Freedman, M.R., 2010. Development , Evaluation, and Validation of College Nutrition Environment. Journal of American College Health, 58(6), pp.565-568.

Gibson, J.C. et al., 2011. Education and Training of Sport Dietitians in Canada: A Review of Current Practice. Canadian Journal Diet Research, 72, pp.88-91.

Habibi, E. et al., 2014. Study of the relationship between the aerobic capacity ( VO2 max ) and the rating of perceived exertion based on the measurement of heart beat in the metal industries Esfahan. Journal od Education and Health Promotion, 3(June).

$\mathrm{Hu}, \mathrm{C}$. et al., 2009. Evaluation of a kindergarten-based nutrition education intervention for preschool children in China. Public Health Nutrition, 13(2), pp.253260.

Isbell, M.G. et al., 2015. Development and Implementation of ClientCentered Nutrition Education Programs in a 4-Stage Framework. American Journal Public Health, 
105(4), pp.65-71.

James, C., 2001. Integrating evaluation tools to assess nutrition education. Jornal of Nutrition Educatiob, 33(S2).

Khandelwal, S. \& Kurpad, A., 2014. Nurturing public health nutrition education in India. European Journal of Clinical Nutrition, 68(5), pp.539-540. Available at: http://dx.doi.org/10.1038/ejcn.2014 .42 .

Kicklighter, J.R. et al., 2007. College Freshmen Perceptions of Effective and Ineffective Aspects of Nutrition Education. Journal of American College Health, 59(2).

Kim, M. \& Claudia, W., 2003. REAP and WAVE: New tools to rapidly assess / discuss nutrition with patients. The Journal of nutrition, Supplement.

Kostanjevec, S., 2012. Nutrition knowledge in relation to the eating behaviour and attitudes of Slovenian schoolchildren. Nutrition and Food Science, 43(6), pp.564573.

Lodha, S. \& Bharti, V., 2015. Impact of Nutrition Education on Hemoglobin Levels of 6 to 18 Months Infants. International Journal of Food Nutrition and Dietetics, 3(2), pp.51-58.

Lyons, B.P., 2014. Nutrition Education Intervention with CommunityDwelling Older Adults: Research Challenges and Opportunities. Journal Community Health, (39), pp.810-818.

Maclellan, D., Sciences, N. \& Edward, P., 2011. Toward Evidence-based, Client-centred Nutrition Education Guidelines: Dietitian and Consumer Survey Results. Canadian Journal Diet Research, 72(3).

Mann, S., Beedie, C. \& Jimenez, A., 2014. Differential Effects of Aerobic Exercise, Resistance Training and Combined Exercise Modalities on Cholesterol and the Lipid Profile: Review, Synthesis and Recommendations. Sport Medicine, pp.211-221.
Maughan, R.J. \& Shirreffs, S.M., 2012. Plenary Lecture 2 Nutrition for sports performance: issues and opportunities. Proceeding of the Nutrition Society, (July 2011), pp.112-119.

Melo, X. et al., 2011. Comparing several equations that predict peak $\mathrm{V} \mathrm{O} 2$ using the 20-m multistage-shuttle run-test in 8 - 10-year-old children. Eur Journal App; Physio, 111, pp.839-849.

Mujika, I. \& Burke, M., 2011. Nutrition in Team Sports. Nutrition and Metabolism, 57(suppl 2), pp.2635.

Nursing, P. \& Source, A.H., 2009. FITNESS TEST RESULTS OF HUNGARIAN AND INTERNATIONAL-LEVEL SOCCER REFEREES AND ASSIS. Journal of Strength And Conditioning Research, 23(1).

Papadopoulou, S.K. \& Papadopoulou, S.D., 2010. Nutritional status of top team-sport athletes according to body fat. Nutrition and Food Science, 40(1), pp.64-73.

Reis, J.F. et al., 2012. Effects of aerobic fitness on oxygen uptake kinetics in heavy intensity swimming. Eur Journal Appl Physio, 112, pp.1689-1697.

Royall, D., 2015. Nutrtition Support for Athletes. Canadian Journal Diet Research, 76.

Taylor, J.P., Mckenna, M.L. \& Butler, G.P., 2010. Monitoring and Evaluating School Nutrition and Physical Activity Policies. Canadian Journal of Public Health, 101.

Torres-mcgehee, T.M. et al., 2012. Sports Nutrition Knowledge Among Collegiate Athletes, Coaches, Athletic Trainers, and Strength and Conditioning Specialists. Journal of Atheletic Training, 47(2), pp.205211.

Wilund, K.R. et al., 2009. Effects of Endurance Exercise Training on Markers of Cholesterol Absorption and Synthesis. , 8408, pp.545552. 


\section{LAMPIRAN}

Tabel 1. Karakteristik Responden

\begin{tabular}{|l|l|c|c|c|c|}
\hline \multirow{2}{*}{ Karakteristik } & \multicolumn{1}{|c|}{ Indikator } & \multicolumn{2}{|c|}{ Intervensi } & \multicolumn{2}{c|}{ Kontrol } \\
\cline { 2 - 6 } & & $\mathrm{n}$ & $\%$ & $\mathrm{n}$ & $\%$ \\
\hline \multirow{3}{*}{$\begin{array}{l}\text { Pendidikan } \\
\text { Ayah }\end{array}$} & Tamat SD & 1 & 14,3 & 0 & 0 \\
\cline { 2 - 6 } & Tamat SMP & 1 & 14,3 & 0 & 0 \\
\cline { 2 - 6 } & Tamat SMA & 4 & 57,1 & 1 & 7,7 \\
\cline { 2 - 6 } & Perguruan Tinggi & 1 & 14,3 & 12 & 92,3 \\
\hline \multirow{3}{*}{$\begin{array}{l}\text { Pendidikan } \\
\text { Ibu }\end{array}$} & Tamat SD & 1 & 14,3 & 1 & 7,7 \\
\cline { 2 - 6 } & Tamat SMP & 0 & 0,00 & 1 & 7,7 \\
\cline { 2 - 6 } & Tamat SMA & 4 & 57,1 & 0 & 0.0 \\
\cline { 2 - 6 } & Perguruan Tinggi & 2 & 28,6 & 11 & 84,6 \\
\hline \multirow{4}{*}{ Status Gizi } & Kurus & 0 & 0,00 & 9 & 69,2 \\
\cline { 2 - 6 } & Normal & 0 & 0,00 & 2 & 15,4 \\
\cline { 2 - 6 } & Obesitas 1 & 6 & 85,7 & 0 & 0,0 \\
\cline { 2 - 6 } & Obesitas 2 & 1 & 14,3 & 0 & 0,0 \\
\cline { 2 - 6 } & Berisiko & 0 & 0,00 & 0 & 0,0 \\
\hline
\end{tabular}

Tabel 1. Pengetahuan Gizi Sebelum dan Setelah Intervensi

\begin{tabular}{|c|c|c|c|c|c|}
\hline \multirow{2}{*}{ Variable } & \multicolumn{2}{|c|}{ Intervensi } & \multicolumn{2}{c|}{ Kontrol } & \multirow{2}{*}{ Man- Witney $(\mathrm{p})$} \\
\cline { 2 - 5 } & $\mathrm{n}$ & $\%$ & $\mathrm{n}$ & $\%$ & \\
\hline Pra Intervensi & & & 37,5 & 6,4 & \multirow{2}{*}{0,999} \\
\hline 1. Baik & 0 & 0 & 0 & 0 & \\
2. Kurang & 7 & 100 & 13 & 100 & \multirow{2}{*}{0,456} \\
\hline Pasca Intervensi & & & & & \\
\hline 1. Baik & 5 & 71,4 & 7 & 53,8 & \\
2. Kurang & 2 & 28,6 & 6 & 46,2 & \\
\hline
\end{tabular}

Tabel 2. Kategori Pengetahuan Sebelum dan Setelah Intervensi

\begin{tabular}{|c|c|c|c|c|c|c|}
\hline \multirow{2}{*}{ Variable } & \multicolumn{2}{|c|}{ Intervensi } & & \multicolumn{2}{|c|}{ Kontrol } & \multirow{2}{*}{$\begin{array}{l}\text { Man- } \\
\text { Witney } \\
\text { (p) }\end{array}$} \\
\hline & $\mathrm{n}$ & $\%$ & & $\mathrm{n}$ & $\%$ & \\
\hline Pra Intervensi & & & \multirow{4}{*}{0,063} & & & \multirow{4}{*}{0,016} \\
\hline $\begin{array}{ll}\text { 1. } & \text { Baik } \\
\text { 2. } & \text { Kurang }\end{array}$ & $\begin{array}{l}0 \\
7\end{array}$ & $\begin{array}{c}0 \\
100\end{array}$ & & $\begin{array}{c}0 \\
13\end{array}$ & $\begin{array}{c}0 \\
100\end{array}$ & \\
\hline Pasca Intervens & & & & & & \\
\hline $\begin{array}{ll}\text { 1. } & \text { Baik } \\
\text { 2. } & \text { Kurang }\end{array}$ & $\begin{array}{l}5 \\
2\end{array}$ & $\begin{array}{l}71,4 \\
28,6\end{array}$ & & $\begin{array}{l}7 \\
6\end{array}$ & $\begin{array}{l}53,8 \\
46,2\end{array}$ & \\
\hline
\end{tabular}

Tabel 3. Asupan Gizi Makro Sebelum dan Setelah Intervensi

\begin{tabular}{|l|c|c|c|c|c|c|}
\hline \multirow{2}{*}{ Variable } & \multicolumn{2}{|c|}{ Intervensi } & \multirow{2}{*}{$(p)$} & \multicolumn{2}{|c|}{ Kontrol } & \multirow{2}{*}{$(p)$} \\
\cline { 2 - 3 } & Rerata & SD & & Rerata & SD & \\
\hline
\end{tabular}




\begin{tabular}{|c|c|c|c|c|c|c|}
\hline Karbohidrat Pra* & 298,6 & 38,0 & \multirow{2}{*}{0280} & 275,1 & 35,8 & \multirow{2}{*}{0,688} \\
\hline Karbohidrat Post* & 296,9 & 36,7 & & 277,8 & 35,6 & \\
\hline Protein Pra** & 72,3 & 7,9 & \multirow{2}{*}{1,000} & 52,1 & 10,7 & \multirow{2}{*}{0,625} \\
\hline Protein Post ${ }^{\star \star}$ & 70,0 & 11,1 & & 55,1 & 7,4 & \\
\hline Lemak Pra* & 51,7 & 5,5 & \multirow{2}{*}{0,553} & 48,8 & 6,1 & \multirow{2}{*}{0,309} \\
\hline Lemak Post* & 52,9 & 3,6 & & 47,8 & 4,0 & \\
\hline Asupan Energi Post * & $1.943,1$ & 144,8 & \multirow{2}{*}{0,781} & $1.761,3$ & 137,6 & \multirow{2}{*}{0,666} \\
\hline Asupan Energi Pra * & $1.948,9$ & 159,7 & & $1.747,5$ & 185,8 & \\
\hline
\end{tabular}

Keterangan : ${ }^{*}=\mathrm{t}$ Test sedangkan ${ }^{* *}$ Test Nonparameterik Mc Nemar

Tabel 4. Asupan Gizi Makro Kelompok Intervensi dengan Kontrol

\begin{tabular}{|l|c|c|c|c|c|}
\hline \multirow{2}{*}{ Variable } & \multicolumn{2}{|c|}{ Intervensi } & \multicolumn{2}{c|}{ Kontrol } & t-Test \\
\cline { 2 - 5 } & Rerata & SD & Rerata & SD & \\
\hline Karbohidrat Pra* & 298,6 & 38,0 & 275,1 & 35,8 & 0,204 \\
\hline Karbohidrat Post* & 296,9 & 36,7 & 277,8 & 35,6 & 0,284 \\
\hline Protein Pra $^{* *}$ & 72,3 & 7,9 & 52,1 & 10,7 & 0,001 \\
\hline Protein Post** $^{*}$ & 70,0 & 11,1 & 55,1 & 7,4 & 0,048 \\
\hline Lemak Pra* $^{*}$ & 51,7 & 5,5 & 48,8 & 6,1 & 0,292 \\
\hline Lemak Post $^{\star}$ & 52,9 & 3,6 & 47,8 & 4,0 & 0,013 \\
\hline Asupan Energi Post & \\
\hline Asupan Energi Pra & $1.943,1$ & 144,8 & $1.761,3$ & 137,6 & 0,019 \\
\hline
\end{tabular}

Keterangan : ${ }^{*}=\mathrm{t}$ Test sedangkan ${ }^{* *}$ Test Nonparameterik Man Witney

Tabel 5. Kadar Kholesterol Total Sebelum dan Setelah Intervensi

\begin{tabular}{|c|c|c|c|c|c|c|}
\hline \multirow{2}{*}{ Variable } & \multicolumn{2}{|c|}{ Intervensi } & \multirow{2}{*}{$\begin{array}{c}\text { t-Test } \\
\text { (p) }\end{array}$} & \multicolumn{2}{|c|}{ Kontrol } & \multirow{2}{*}{$\begin{array}{l}\text { t-Test } \\
\text { (p) }\end{array}$} \\
\hline & Rerata & SD & & Rerata & SD & \\
\hline Kholesterol Pra & 222,7 & 7,6 & \multirow{2}{*}{0,744} & 211,5 & 10,5 & \multirow{2}{*}{0,252} \\
\hline Kholesterol Post & 222,4 & 6,5 & & 211,0 & 10,5 & \\
\hline
\end{tabular}

Keterangan : Uji Kolmogrof Data berdistribusi normal $(p=0,056)$

Tabel 6. Kadar Kholesterol Total Kelompok Intervensi dengan Kontrol

\begin{tabular}{|l|c|c|c|c|c|}
\hline \multirow{2}{*}{ Variable } & \multicolumn{2}{|c|}{ Intervensi } & \multicolumn{2}{c|}{ Kontrol } & t-Test \\
\cline { 2 - 5 } & Rerata & SD & Rerata & SD & \\
\hline Kholesterol Pra & 222,7 & 7,6 & 211,5 & 10,5 & 0,015 \\
\hline Kholesterol Post & 222,4 & 6,5 & 211,0 & 10,5 & 0,008 \\
\hline
\end{tabular}

Tabel 7. Volume Oksigen Maksimum Sebelum dan Setelah Intervensi

\begin{tabular}{|c|c|c|c|c|c|c|}
\hline \multirow{2}{*}{ Variable } & \multicolumn{2}{|c|}{ Intervensi } & \multirow{2}{*}{$\begin{array}{c}\text { t-Test } \\
\text { (p) }\end{array}$} & \multicolumn{2}{|c|}{ Kontrol } & \multirow{2}{*}{$\begin{array}{l}\text { t-Test } \\
\text { (p) }\end{array}$} \\
\hline & Rerata & SD & & Rerata & SD & \\
\hline $\begin{array}{l}\mathrm{VO}_{2} \text { Maks Pra } \\
\text { Intervensi }\end{array}$ & 35,3 & 0,8 & \multirow{2}{*}{0,001} & 34,2 & 1,1 & \multirow{2}{*}{0,054} \\
\hline $\begin{array}{l}\mathrm{VO}_{2} \text { Maks Post } \\
\text { intervensi }\end{array}$ & 37,0 & 1,3 & & 34,6 & 1,1 & \\
\hline
\end{tabular}

Keterangan : Uji Kolmogrof Data berdistribusi normal $(p=0,969)$

Tabel 9 Volume Oksigen Maksimum Kelompok Intervensi dengan Kontrol 


\begin{tabular}{|l|c|c|c|c|c|}
\hline \multirow{2}{*}{ Variable } & \multicolumn{2}{|c|}{ Intervensi } & \multicolumn{2}{c|}{ Kontrol } & $\begin{array}{c}\text { t-Test } \\
(p)\end{array}$ \\
\cline { 2 - 5 } & Rerata & SD & Rerata & SD & 0,313 \\
\hline $\begin{array}{l}\mathrm{VO}_{2} \text { Maks Pra } \\
\text { Intervensi }\end{array}$ & 34,7 & 0,7 & 34,2 & 1,1 & 0,002 \\
\hline $\begin{array}{l}\mathrm{VO}_{2} \text { Maks Post } \\
\text { intervensi }\end{array}$ & 37,0 & 1,3 & 34,6 & 1,1 & 0,6 \\
\hline
\end{tabular}

Keterangan : Uji Kolmogorof Data berdistribusi normal $(p=0,969)$ 